\title{
Ocular Parameter Changes in Pediatric Patients with Nephrotic Syndrome
}

\author{
WESAM E. AFIFI, M.D.*; AHMED A. TABL, M.D.**; MAHMOUD A. ABD EL MOHSEN, M.Sc.*** and \\ MOHAMED S. SLEEM, M.D.*
}

The Departments of Pediatric Nephrology* and Ophtalmology**, Faculty of Medicine, Benha University and The Department of Pediatrics, Benha Children Hospital, Ministry of Health***, Egypt

\begin{abstract}
Background: Nephrotic syndrome has a relapsing nature that necessitates prolonged use of steroids and other immunosuppressive drugs. Systemic steroid administration is associated with multiple ocular side effects. This study was conducted to report various ocular manifestations in pediatric patients with nephrotic syndrome.
\end{abstract}

Aim Study: The aim of our study is to report various ocular manifestations in children with idiopathic nephroticsyndrome.

Patients and Methods: This cross-sectional case control study included 100 cases diagnosed with nephrotic syndrome and 50 healthy controls. All subjects were subjected to detailed history taking, general examination, and laboratory investigations. Also, comprehensive ophthalmological examination (including visual acuity, slit lamp microscopy, intraocular pressure measurement, and fundus examination) were performed.

Results: Unaided visual acuity was significantly increased in cases compared to controls, and that was evident in both right and left eyes. IOP was significantly elevated in cases compared to controls $(p<0.001)$. Cataract was detected in 4 cases $(4 \%)$. Right eye fundus examination revealed abnormalities in 12 cases $(12 \%)$. The mean duration of disease in our study was 2.22 years (range, 6 months- 9 years). Disease duration had no significant association with neither of IOP, cataract, nor fundus examination $(p>0.05)$.

Conclusion: There is an increased incidence of ocular complications in pediatric cases with nephrotic syndrome. It is recommended that these cases should have regular ophthalmological examination for early detection of these complications.

Key Words: Nephrotic syndrome - Steroids - Ocular side effects.

Correspondence to: Dr. Wesam E. Afifi, The Department of Pediatrics Nephrology, Faculty of Medicine, Benha University, Egypt

\section{Introduction}

NEPHROTIC syndrome is a clinical entity characterized by massive proteinuria $\left(>40 \mathrm{mg} / \mathrm{m}^{2} /\right.$ hour $)$ responsible for hypoalbuminemia $(<3 \mathrm{~g} / \mathrm{L})$, with resulting hyperlipidemia, edema, and variouscomplications. It is there sultofanab normality of glomerularpermeability that may be primary with a disease-specific to the kidneys or secondary to congenital infections, diabetes, systemic lupus erythematosus, neoplasia, or certain drug use [1]

Nephrotic syndrome is the commonest cause of glomerulopathy in children aged between 2 and 18 years [2], with a prevalence of about 16 cases per 100,000 [3]. In Egypt, nephrotic syndrome constitutes a significant health issue in children as previously reported in Bakr et al. [4]. The latter report revealed the increased incidence of newly diagnosed cases over years and increased frequency of steroid-resistant cases. Therefore, frequent complications, hospital admission, use of multiple immunosuppressive drugs are anticipated [5]

Corticosteroid therapy is the cornerstone in managing such cases. Despite its efficacy, its systemic administration is associated with multiple ophthalmic complications along with other system affection [6]. As nephrotic syndrome has a relapsing course, it is preferred to commence cases on a prolonged steroid course [7].

A previous Iranian study has reported that cases with nephrotic syndrome can develop steroid dependent and independent ocular side effects. Steroid dependent side effects include open angle glaucoma, posterior subcapsular cataract, and macular pigment changes. Independent effects include exotropia, myopic astigmatism, along with Mittendorf's dot [8] 


\section{Patients and Methods}

This is across sectional case control study designed for children diagnosed with idiopathicnephrotic syndrome. It was conducted during the period of one year, starting from February 2019 till February 2020.

A total of 150 subjects $(n=150)$ were included in the study; cases group which included 100 cases with idiopathic nephrotic syndrome, and control group which included 50 healthy children.

\section{Inclusion criteria:}

- Patients between 2-18 years of age.

- Diagnosis of nephrotic syndrome for at least 6 months. It was classically characterized by four clinical features: Urinary protein excretion greater than $50 \mathrm{mg} / \mathrm{kg} /$ day, serum albumin concentration $<3 \mathrm{gm} / \mathrm{dl}$, edema, and hyperlipidemia [9]

\section{Exclusion criteria:}

- Patients $<1$ year or older than 18 years.

- Having systemic diseases other than nephrotic syndrome.

- Disease duration ${ }^{<6}$ months.

- Previous ocular trauma or history of previous eye surgery.

- Refusal to participate in the study by the child parents.

An informed written consentwere obtained from child parents before the study after complete description of the benefits of these investigations. Also, the study was approved by the Local Ethical Committee of Benha University.

All cases were subjected to complete history taking, thorough general examination, ophthalmic examination in addition to laboratory investigations.

\section{History:}

-Personal history: Age, sex, residence, and socioeconomic status.

- Present history: Onset, course and duration of edema, poor vision, blurred vision, nystagmus, history of polyuria, polydipsia, polyphagia, history suggestive bleeding disorder, and trauma.

- History of drug intake e.g., corticosteroids and immunosuppressive agents. Type of treatment, its duration, and dates and number of relapses were recorded. The overall amounts of prednisone dose that each patient received during therapy were calculated.
- Past history: Other diseases and operations.

- Family history: Eye diseases, renal problems, diabetes mellitus, and hypertension.

\section{Examination:}

- General: Vital signs (pulse, temperature, respiratory rate and blood pressure), Anthropometric measurements (weight and height), presence or absence of edema and skin rash.

- Local: Ophthalmic, abdominal, cardiac, CNS and chest examination.

\section{Investigations:}

- Complete blood count.

- Serum albumin level.

- Renal function tests (serumcreatinine and urea).

- Serum Na, K, Ca, and P.

- Random blood sugar.

- Urine analysis.

- 24 hours protein in urine.

- Serum cholesterol level.

- Renal biopsy which was done before study.

\section{Ophthalmological assessment:}

Comprehensive ophthalmological examination was performed including eye inspection, Unaided Visual Acuity (UAVA), Best Corrected Visual Acuity (BCVA), Intraocular Pressure (IOP) measurement by applanation tonometry, slit lamp microscopy after pupil dilatation, in addition to fundus examination.

\section{Statistical analysis:}

The clinical data were recorded on a report form. These data were tabulated and analyzed using the computer program SPSS (Statistical Packagefor Social Science) version 26. Descriptive statistics were calculated for the data in the form of mean and standard deviation for quantitative data, and frequency with distribution for qualitative data. Student's $t$-test was used to compare two groups of quantitative data where as inter-group comparison of categorical data was performed by using Fisher Exact Test (FET). A $p$-value $<0.05$ was considered statistically significant while $>0.05$ statistically insignificant $p$-value $<0.01$ was considered highly significant in all analyses.

\section{Results}

In this study, there was no significant difference between the two groups regarding gender $(p=0.2)$. 
Males represented $63 \%$ of cases in the current study. The mean age of the included cases was 8.22 years, which was significantly younger than controls (10.03 years). The mean BMI of the included cases was $24.11 \mathrm{~kg} / \mathrm{m}^{2}$, which was significantly higher than controls.

The mean duration of disease in our study was 2.22 years (range, 6 months- 9 years). Most of the included cases were steroid sensitive (88\%), while the remaining cases were steroid resistant. In addition, the most common pathologies detected at biopsy were minimal change disease (70\%), followed by focal segmental glomerular sclerosis $(25 \%)$.

UAVA was significantly increased in casescompared to controls, and that was evident inboth right and left eyes. Visual acuity had mean values of 0.2 and 0.02 in the right eye, 0.198 and 0.012 in the left eye, in both groups respectively. IOP was significantly elevated in cases compared to controls $(p<0.001)$. It had mean values of 19.5 and 19.61 in cases, compared to 14.84 and 14.56 in controls, in right and left eyes respectively therefore treatment was advised on the other hand, IOP mean values 65 and 59 in cases, in right and left eyes respectively advised for follow-up (Table (1) shows these data.

Table (1): UAVA, BCVA, and IOP in cases versus controls.

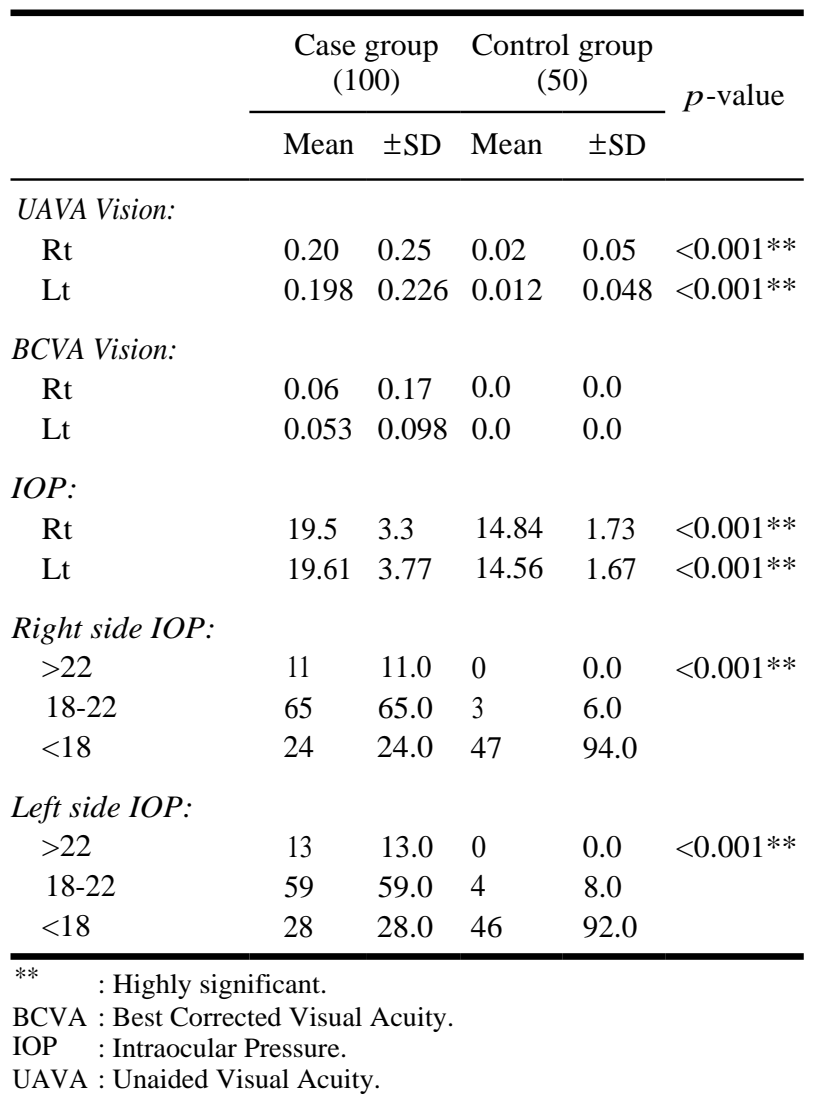

Regarding the presence of cataract in our study, cataract was detected in 4 cases $(4 \%)$. Right eye fundus examination revealed abnormalities in 12 cases (12\%) as follows; $\mathrm{A} / \mathrm{V}$ crossing bilateral (8\%), elevated optic disc (2\%), and A/V crossing and tortuous retinal veins $(2 \%)$. The same findings were detected in the left eyes with the same prevalence. These data are summarized at (Table 2).

Table (2): Slit lamp and fundus examination findings in the study cases.

\begin{tabular}{lll}
\hline Examination findings & No & $\%$ \\
\hline $\begin{array}{l}\text { Slit lamp cataract: } \\
\text { Right side: }\end{array}$ & & \\
- Cataract with capsular phimosis \& & 2 & 2.0 \\
$\quad$ posterior capsular opacity & & \\
- PSC & 2 & 2.0 \\
- NAD & 96 & 96.0 \\
Left side: & & \\
- PSC & 2 & 2.0 \\
- Faint PSC & 2 & 2.0 \\
- NAD & 96 & 96.0 \\
Fundus examination: & & \\
Right side: & & \\
- A/V crossing bilateral & 8 & 8.0 \\
- Can't be assessed & 2 & 2.0 \\
- Slightly elevated optic disc & 2 & 2.0 \\
- Tortious retinal veins \& AV crossing & 2 & 2.0 \\
bilaterally & & \\
- NAD & 86 & 86.0 \\
Left side: & & \\
- A/V crossing bilateral & 8 & 8.0 \\
- Slightly elevated optic disc & 2 & 2.0 \\
- Tortious retinal veins \& AV crossing & 2 & 2.0 \\
bilaterally & & \\
- NAD & 88 & 88.0 \\
\hline
\end{tabular}

PSC : Posterior Subcapsular Cataract.

AV : Arteriovenous.

NAD : No Abnormality Detected.

Regarding to relation between drugs and ocular findings in the current study, both cyclophosphamide and cyclosporin appeared to have no significant effect on any of the studied ocular parameters $(p>0.05)$. Anticoagulant therapy did not have a significant impact on the ocular parameters, apart from left sided IOP which was $>22 \mathrm{mmHg}$ in the two cases receiving that therapy $(100 \%)$. Mycophenolate therapy appeared to have no significant effect on the ocular findings, apart from right side IOP that was significantly higher in cases commenced on that therapy versus who did not ( $p=$ $0.019)$. IOP $>22 \mathrm{mmHg}$ was detected in 40 and $7.8 \%$ of cases in both groups respectively.

There was no significant difference between cases and controls regarding the tested electrolytes including $\mathrm{Na}, \mathrm{K}$, and $\mathrm{Ph}$. Never the less, calcium 
levels were significantly decreased in cases compared to controls.

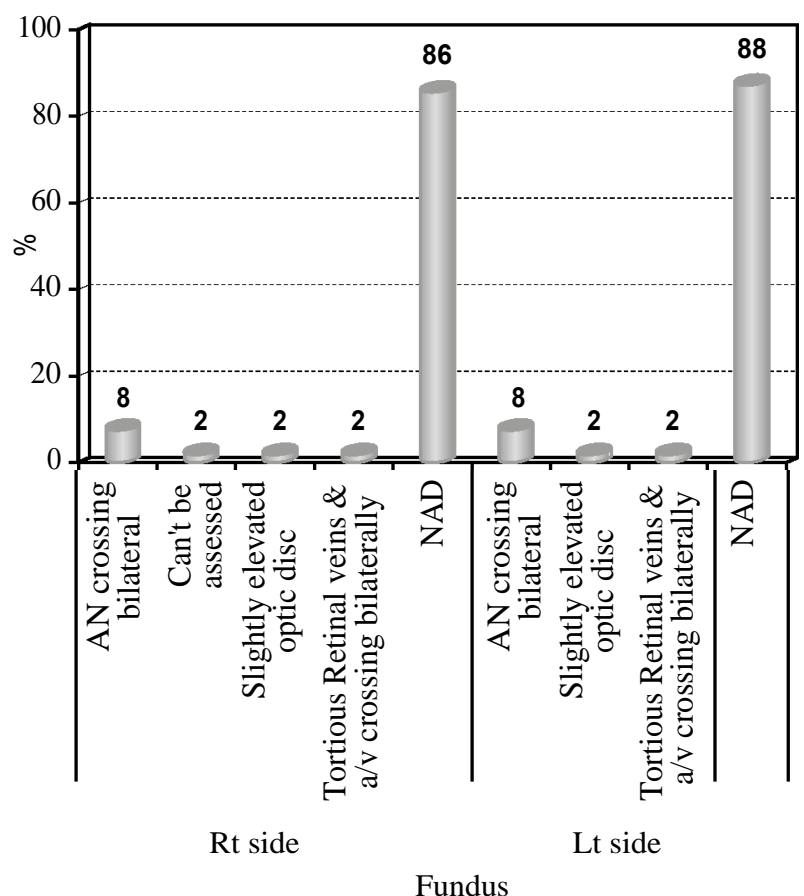

Graph (1): Shows retinal findings in studied cases.

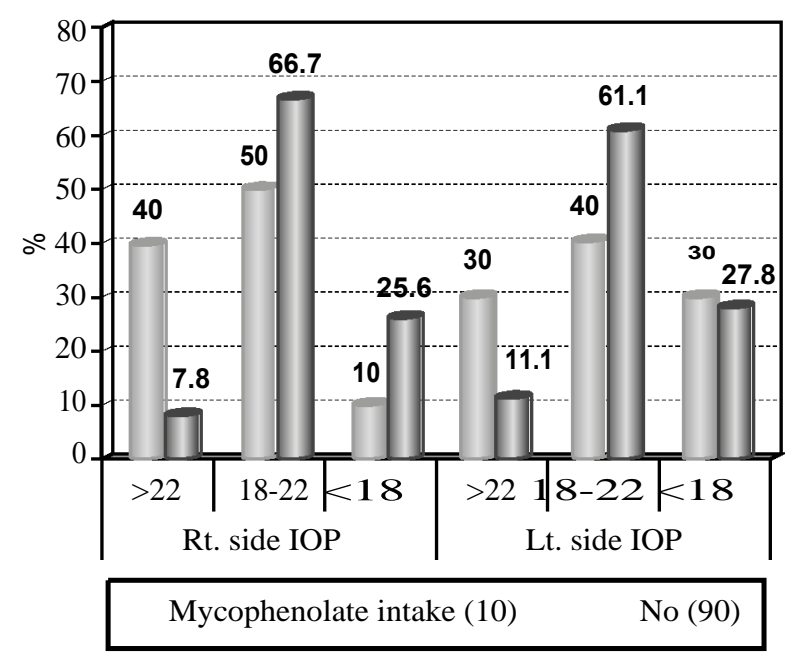

Graph (2): Shows IOP parameters in cases receiving mycophenolate therapy.

\section{Discussion}

This current study showed that ocular side effects are not uncommon in children with nephrotic syndrome receiving high dose of systemic steroids and this is in agreement with Nakubulwa et al., who estimated that the prevalence of ocular complications in such cases may reach up to $80 \%$ [2]

In this study, we included a total of 100 cases with nephrotic syndrome who were compared to
50 healthy controls which showed no significant difference between the two groups regarding gender $(p=0.2)$. Males represented $63 \%$ of cases in the currentstudy.

In our study, there was statistically significant difference between the two groups regarding age as the mean age of the included cases was 8.22 years while the mean age of controls was 10.03 years and this is in agreement with Nakubulwa et al., [2] who in a recent study handling the same perspective, the majority of the included cases had their age ranged between 7 and 12 years.

Our study revealed that there was statistically different between case group and control group regarding BMI as that of the included cases was $24.11 \mathrm{~kg} / \mathrm{m}^{2}$, which was significantly higher than controls (mean $=17.47-p<0.001$ ) this could be due to salt and water retention in nephrotic syndrome [11], also, increased BMI is a common complication of steroid therapy [12].

Additionally, the study revealed that there was statistically significant difference between the two groups regarding IOP as the mean value in the case group was higher than the control group $p<0.001$ ). It had mean values of 19.5 and 19.61 incases, compared to 14.84 and 14.56 in controls, in right and left eyes respectively. Moreover, this was in agreement with Shiota [13] who reported that systemic steroid administration is associated with secondary open angle glaucoma, and the raised IOP decreased gradually after drug cessation [13] Many theories could explain that side effects. Steroids may increase aqueous production, or it may cause a decrease in the facility of outflow. Besides, there is overaccumulation of mucopolysaccharides in the trabecular meshwork leading to trabecular dysfunction.

The study showed that the majority of cases (96\%) in case group had no abnormalities during slit lamb examination while cataract was detected in 4 cases $(4 \%)$. This was in agreement with $\mathrm{Na}-$ kubulwa et al., [8] who reported that cataract was encountered in 1 case (1\%) [2]. In addition, Gheissari et al., reported that the prevalence of subcapsular cataract was $9.3 \%$ in their study.

Multiple studies have documented that there is a significant association betweensystemic steroid therapy and cataract [14]. Posterior subcapsular cataract is a distinctive feature of oral steroids. Steroids induce some chemical alternations in the crystalline lens that free the sulfhydryl group from the disulfide bonds leading to protein aggregation and lens opacity. Also, aberrant migration of lens 
epithelial cells may play a role. Other mechanisms include free oxygen species formation, genetic mutations, and change of intraocular growth factor homeostasis [15].

In the current study, right eye fundus examination revealed abnormalities in 12 cases $(12 \%)$ asfollows; A/V crossing bilateral (8\%), elevated opticdisc (2\%), and $\mathrm{A} / \mathrm{V}$ crossing and tortuous retinal veins $(2 \%)$. The same findings were detected in the left eyes with the same prevalence. These finding may be attributed to the hypercoagulable state present in nephrotic syndrome. This was in agreement with $\mathrm{Ng}$ and his colleagues reported in their case series that all the three cases had asymptomatic dilated tortuous retinal vessels on the arterial and venous sides [16], while this was in disagreement with Gheissari et al., [8] who reported neither of the signs reported by ours. However, macular pigment changes were detected in 3 cases $(4 \%)$.

In our study, the duration of the disease had no significant association with neither of IOP, cataract, nor fundus examination $(p>0.05)$. There was no significant differencebetween the subgroups related to either of the three variables regarding diseaseduration. This was in disagreement with Nakubulwa et al., [2] who reported that age $>10$ years, steroid dependent nephrotic syndrome, frequent relapses, and increased cumulative steroid dose are significant risk factors for ocular complications on bivariate analysis.

When cases were divided according to antihypertensive medications intake, IOP was significantly higher in patients receiving antihypertensive medicationsas IOP $>22 \mathrm{mmHg}$ was detected in 57.1 and $71.4 \%$ of right and left eyes respectively in such cases, compared to 7.5 and $8.6 \%$ of cases not receiving these medications. Other ocular findings did not show significant differences between the two groups. In our study, both cyclophosphamide and cyclosporin appeared to have no significant effect on any of the studied ocular parameters $(p$ $>0.05$ ) and this agreed Olonan et al., [10] who reported that combined steroid and immunosuppressive therapy did not increase the incidence of glaucomaor cataract in nephrotic syndrome patients. Also, Sihota et al., [13] revealed that there was no significant difference between the steroid only and combined groups regarding the incidence of ocular complications $(p>0.05)$. Cataract was present in $33 \%$ of cases in both groups, while elevated IOP was diagnosed in 19 and $21 \%$ of cases in both groups respectively.
In the current study, anticoagulant therapy did not have a significant impact on the ocularparameters, a part from left sided IOP which was $>22 \mathrm{mmHg}$ in the two cases receiving that therapy $(100 \%)$.

In our study, mycophenolate therapy appeared to have no significant effect on the ocularfindings, a part from right side IOP that was significantly higher in cases commenced on that therapy versus who did not $(p=0.019)$. IOP $>22 \mathrm{mmHg}$ was detected in 40 and $7.8 \%$ of cases in both groups respectively. However, this was in disagreement with Daniel et al., who reported that mycophenolate is a safe drug for the eye, even it is prescribed in cases with persistent ocular inflammation [17]. Of note, when we classified the study cases according to the drug treatment, small subgroups were developed, which weaken the statistical comparison between the two groups. Therefore, larger studies are needed to elucidate that matter. Also, steroid induced ocular side effects are well established, and even it may be the only cause of these complications. Our study has several limitations, first of all, it is a single center study, and the included sample was relatively small. Also, the cumulative dose of each drug should have been estimated to furtherly explain the relationship with ocular sideeffects.

\section{Conclusion:}

All of all, we should clarify that there is an increased incidence of ocular complications in children with nephrotic syndrome. It is recommended that these cases should have regular ophthalmological examination for early detection of these complications. Also, more studies should be conducted to identify the risk factors for developing these complications.

\section{References}

1- RAINA R. and KRISHNAPPA V.: An update on LDL apheresis for nephrotic syndrome. Pediatric Nephrology, 34 (10): 1655-69, 2019.

2- NAKUBULWA F., LUSOBYA R.C., BATTE A., et al. Prevalence and predictors of ocular complications among children with nephrotic syndrome in a resource-limited setting, 2020.

3- EDDY A.A. and SYMONS J.M.: Nephrotic syndrome in childhood. The lancet, 362 (9384): 629-39, 2003.

4- BAKR A., EID R., SARHAN A., et al.: Pathological profile of biopsied Egyptian children with primary nephrotic syndrome: 15-year single center experience. Journal of Nephrology, 27 (4): 419-23, 2014.

5- EID R., FATHY A.A. and HAMDY N.: Health-related quality of life in Egyptian children with nephrotic syndrome. Quality of Life Research: 1-12, 2020. 
6- LIU D., AHMET A., WARD L., et al.: A practical guide to the monitoring and management of the complications of systemic corticosteroid therapy. Allergy, Asthma \& Clinical Immunology, 9 (1): 30, 2013.

7- GAUR S., JOSEPH M., NITYANANDAM S., et al.: Ocular complications in children with nephrotic syndrome on long term oral steroids. The Indian Journal of Pediatrics, 81 (7): 680-3, 2014.

8- GHEISSARI A., ATTARZADEH H., SHARIF H., et al.: Steroid dependent and independent ocular findings in Iranian children with nephrotic syndrome. International Journal of Preventive Medicine, 2 (4): 264, 2011.

9- NIAUDET P.: Etiology, clinical manifestations, and diagnosis of nephrotic syndrome in children. Up To Date version, 16, 2014.

10- OLONAN L.R.N., PANGILINAN C.A.G. and YATCO M.M.: Steroid-induced cataract and glaucoma in pediatric patients with nephrotic syndrome. Philippine Journal of Ophthalmology, 34 (2): 59-62, 2009.

11- De BENEDETTO U., PASTORE M.R., PARODI M.B., et al.: Retinal involvement in nephrotic syndrome secondary to minimal change disease. European Journal of Ophthalmology, 22 (5): 843-5, 2012.
12- HAYASAKA Y., HAYASAKA S. and MATSUKURA H.: Ocular findings in Japanese children with nephrotic syndrome receiving prolonged corticosteroid therapy. Ophthalmologica, 220 (3): 181-5, 2006.

13- SIHOTA R., KONKAL V., DADA T., et al.: Prospective, long-term evaluation of steroid-induced glaucoma. Eye, 22 (1): 26-30, 2008.

14- KACMAR J. and CHOLEVÍK D.: Corticosteroid Induced Posterior Subcapsular Cataract. Ceska a slovenskaoftalmologie: Casopis Ceske of talmologick espolecnostia Slovenske of talmologick espolecnosti, 74 (6): 226-32, 2019.

15- SHARMA P. and GUPTA D.: Corticosteroid Induced Cataract In COPD Patient. JK Science, 21 (1): 48-9, 2019.

16- NG J.S., WONG W., LAW R.W., et al.: Ocular complications of paediatric patients with nephrotic syndrome. Clinical \& Experimental Ophthalmology, 29 (4): 239-43, 2001.

17- DANIEL E., THORNE J.E., NEWCOMB C.W., et al.: Mycophenolatemofetil for ocular inflammation. American Journal of Ophthalmology, 149 (3): 423-32. e2, 2010.

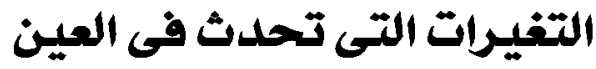 \\ فى الآطفال ذوى المتلازمة النفروزية التية}

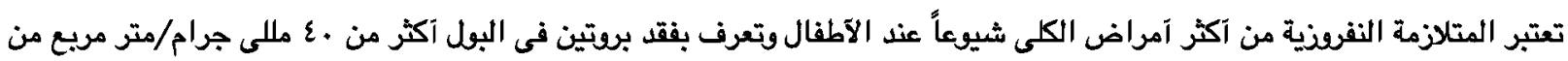

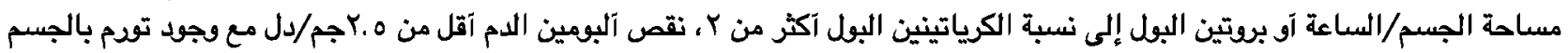

$$
\begin{aligned}
& \text { وإرتفاع نسبة الدهون بالدم. } \\
& \text { يعتبر الستيرويدات هى العلاج الرئيس فى الآطفال ذوى المتلازمة النفروزية. ويما آنها تتميز بحدوث إنتكاثات متكردة، فقد تلقى العديد من } \\
& \text { هؤلاء الآطفال جرعات متعددة و/آو طويلة من بريدنيزولمن النظام وتم إستخدام عدد من الآدوية مثل السيكلوفوسيفاميد وميكوفينولات موفتيل }
\end{aligned}
$$

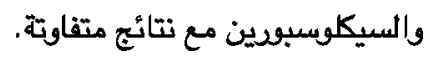

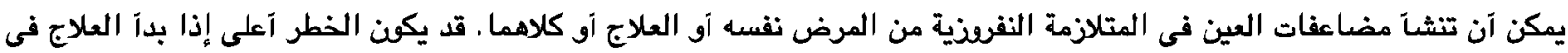

$$
\begin{aligned}
& \text { سن مبكرة. إن العيوب غير الناضجة لهوّلاء المرضى الصغار معرضة لخطر الإصابة بالصل من إعتام علدسة العين. }
\end{aligned}
$$

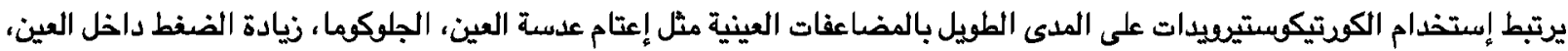

$$
\begin{aligned}
& \text { تدلى الجفون، توبس الحدقة، ضمود جلد الجفن، إلتهاب القرنية، رقة القرئية. } \\
& \text { ومى ذلك، فإن تشوهات تجلط الدم الآكثر شدة فى الآطفال تميل إلى التسبب فى مضاعفات آكثر حدة إذا حدثث. يبدو من المفيد دراسة }
\end{aligned}
$$

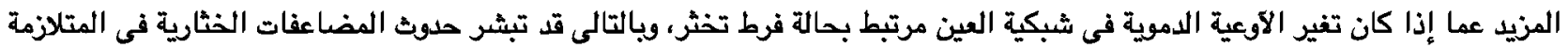

$$
\begin{aligned}
& \text { النفرونية. } \\
& \text { نتانج هذه الدراسة تثير إلى آن الآطفال المرضى بالمتلازمة النفرونية الخاضعين للعلاج بالموتيزنف فقط آو مع علاج آخر آكثر عرضة }
\end{aligned}
$$

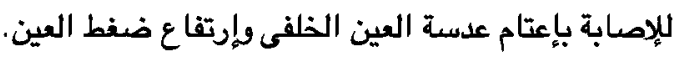

